\title{
FORMULATION, CHARACTERIZATION, AND DETERMINATION OF THE DIFFUSION RATE STUDY OF ANTIOXIDANT SERUM CONTAINING ASTAXANTHIN NANOEMULSION
}

\author{
LUSI NURDIANTI, RISNA CLARA, HENDY SUHENDY, FAJAR SETIAWAN, KENI IDACAHYATI
}

Pharmacy Department, STIKes Bakti Tunas Husada, Jl. Cilolohan 36 Tasikmalaya, West Java, Indonesia

Email: lusinurdianti83@gmail.com

Received: 18 Aug 2021, Revised and Accepted: 01 Oct 2021

\section{ABSTRACT}

Objective: Astaxanthin is one of the natural carotenoids with strong antioxidant characteristics which is widely used in skin care. The aim of this study was developed to formulate and characterize the antioxidant serum containing astaxanthin nanoemulsion and the diffusion rate studies using diffusion Franz method.

Methods: Astaxanthin nanoemulsion (As-NE) was prepared by using the self-nanoemulsifying method, followed by incorporation into serum preparation with the using carbomer as a gelling agent. Evaluation of serum As-NE was performed by physical, chemical characterizations and diffusion assay. Stability study was carried out in both accelerated (temperature of $40 \pm 2{ }^{\circ} \mathrm{C} / 75 \pm 5 \% \mathrm{RH}$ ) and non-accelerated (at ambient temperature) conditions.

Results: These results suggest that antioxidant serum As-NE had good physical and chemical characteristics that are suitable for topical administration.

Conclusion: For the study of diffusion and stability under different storage conditions, it was proven that antioxidant serum As-NE form was packed in a carbomer as a gelling agent that could enhance the stability and diffusion rate of the astaxanthin.

Keywords: Astaxanthin, Nanoemulsion, Antioxidant serum, Diffusion rate, Stability studies

(C) 2021 The Authors. Published by Innovare AcademicSciences Pvt Ltd. Thisis an open access article under the CCBYlicense (https://creativecommons.org/licenses/by/4.0/) DOI: https://dx.doi.org/10.22159/ijap.2021.v13s4.43859 Journal homepage: https://innovareacademics.in/journals/index.php/ijap

\section{INTRODUCTION}

The skin is an organ that covers the entire surface of the body of living things and has a function to protect it from external influences. One of the dangers that can cause skin damage is free radicals. Free radicals can damage molecules whose electrons are attracted by these free radicals, causing cell damage, impaired cell function, and even cell death [1].

Antioxidants are compounds that function to reduce the negative effects of oxidants. Antioxidants work by donating one electron to compounds that are oxidants so that the activity of these oxidant compounds can be inhibited [2]. One of the super antioxidants from natural ingredients is astaxanthin.

Astaxanthin is a xanthophyll carotenoid group with characteristic lipophilic pigment with a reddish colour and, which is naturally synthesized by algae or plants. As a xanthophyll group, which is oxygenated derivatives of carotenes, astaxanthin contains conjugated double bonds, hydroxyl-and keto-groups with lipophilic and hydrophilic properties [3]. Because of its specific structure, astaxanthin acts as a super antioxidant and it showed better biological activity than other antioxidants, because of their ability to link with membrane cells [4-6]. However, carotenoids are unstable to light, oxidizing agents and heat [7]. The low stability requires an effort to protect it. A study was conducted by Nurdianti et al., 2017 to improve the stability of astaxanthin in the preparation, namely by making astaxanthin nanoemulsion formulations [8].

To overcome these weaknesses, the development of astaxanthin nanoemulsion was carried out. Nanoemulsion preparation may offer an increased dissolution rate and absorption rate, while nanoemulsions may also improve release performance $[9,10]$. Furthermore, to facilitate their use in patients; Astaxanthin nanoemulsion was incorporated into serum preparations through topical administration. This research was further research to develop a new dosage form to maximize the use of astaxanthin. In this research, astaxanthin was encapsulated in oil in the oil-in-water nanoemulsion system. This nanoemulsion was developed by selfnanoemulsifying methods. Then, it is combined in serum using carbomer as a gelling agent. Physical evaluation and diffusion and stability tests using the cycling test method were carried out to obtain the quality of the preparations that met the requirements.

\section{MATERIALS AND METHODS}

\section{Materials}

Astaxanthin (Astareal $\AA$ L10) was purchased from Fuji Chemical Industries (Japan). Sunflower oil was purchased from Jan Dekker International (Netherland). Polyoxyl-35-castor oil (Kolliphor® RH40) was purchased from BASF (Indonesia). Polyethylene Glycol 400 (PEG 400) was purchased from Merck (Indonesia). Carbomer was purchased from Brataco, propylene glycol (PT. Bratachem), TEA (PT. Bratachem), methyl paraben (PT. Bratachem), propyl paraben (PT. Bratachem), sodium metabisulfit (PT. Bratachem), aqua DM (PT. Bratachem), DPPH (2,2 diphenyl-1-picrylhydrazyl), Methanol PA (PT. Bratachem). All other chemicals used were of pharmaceutical grade.

\section{Preparation of astaxanthin nanoemulsion}

Astaxanthin nanoemulsion was developed by using a selfnanoemulsifying method with the optimized ratio between the oil phase, surfactant, and co-surfactant, which refers to a previous study [3]. Forty milligrams of astaxanthin were added into the 1 gram mixture of oil phase (Sunflower oil), surfactant (Kolliphor® RH40), and co-surfactant (PEG 400) with the ratio 1:8:1, respectively. This mixture was then mixed with a speed of $100 \mathrm{rpm}$ for $30 \mathrm{~min}$ using a magnetic stirrer (IKA® C-MAG HS7), followed by sonication for 1 hour (Krisbow $®$ ). Nanoemulsion was formed after the addition of deionized water with mild stirring.

Preparation of serum nanoemulsion astaxanthin

In this study, Carbomer was used as a gelling agent, with PEG 400 as a plasticizer. Carbomer was dissolved in deionized water (water temperature $60^{\circ} \mathrm{C}$ ) then homogenized. Propylene glycol, methyl paraben, propylparaben, sodium metabisulfite are added and homogenized, after the serum base is formed. An amount of $0.33 \mathrm{~g}$ astaxanthin nanoemulsion was dispersed slowly into the mixture by using a magnetic stirrer at $100 \mathrm{rpm}$ for $30 \mathrm{~min}$. The serum nanoemulsion astaxanthin composition preparation was given in table 1 . 
Table 1: Composition of serum nanoemulsion astaxanthin

\begin{tabular}{lll}
\hline Name of substance & Function & F0 (\%w/v) \\
\hline SNE astaxanthin & API & F1(\%w/v) \\
Carbomer & Gelling agent & 0.33 \\
Propilen Glikol & Humectan & 0.4 \\
Methyl paraben & Preservative & 10 \\
Propylparaben & Preservative & 0.18 \\
Sodium metabisulfit & Preservative & 0.18 \\
Aqua DM & solvent & 0.02 \\
\hline
\end{tabular}

\section{Visual observation and $\mathrm{pH}$ determination}

Visual observation includes observation of color, odor, and clarity of serum nanoemulsion astaxanthin. A pH of WME was determined by using a calibrated pH meter (Mettler® Toledo) $[11,12]$.

\section{Homogeneity test}

The homogeneity test is carried out by applying the sample to a piece of glass or other suitable transparent material, the preparation must show a homogeneous arrangement and there are no visible coarse grains [12].

\section{Viscosity test}

Viscosity test was carried out using a Brookfield Viscometer. The preparation is put into a beaker. Then the spindle is installed 4 . The spindle must be submerged in the test preparation. The viscometer is turned on and it is ensured that the rotor can rotate at a speed of $50 \mathrm{rpm}$. Observed the needle guide from the viscometer that leads to the viscosity scale and then recorded and multiplied by a factor of 100 [13].

\section{Spreadability test}

The preparation was weighed as much as 0.5 grams and then placed in the middle between 2 glass plates, then given a load of $50 \mathrm{~g}, 100 \mathrm{~g}, 200 \mathrm{~g}$ and left for 1 minute and then the actual area was measured [14].

\section{Cycling test}

The cycling test was carried out for 6 cycles. The gel preparation was stored at a cold temperature of $\pm 4^{\circ} \mathrm{C}$ for $24 \mathrm{~h}$ and then removed and then stored at room temperature $\left(25^{\circ} \mathrm{C}\right)$ for $24 \mathrm{~h}$ and placed at a temperature of $\pm 40^{\circ} \mathrm{C}$, this process was counted as 1 cycle [15].

\section{Diffusion rate test}

The diffusion test was carried out using a Franz diffusion cell with snake skin as a membrane. 0.5 grams of the sample was inserted into $\pm 2.8 \mathrm{~cm}$ of skin. The receptor compartment contains $50 \mathrm{ml}$ of 7.4 phosphate buffer. During the diffusion operation, the temperature was adjusted with a water jacket to keep it constant at $37^{\circ} \mathrm{C} \pm 0.5^{\circ} \mathrm{C}$. Sampling was $1 \mathrm{ml}$ from the receptor compartment at $5,10,15,30,45,60,75,90,105$, and $120 \mathrm{~min}$ and immediately replaced with phosphate buffer $\mathrm{pH} 7.4$ according to the volume taken. The absorbance was measured by UV Vis Spectrophotometry at a wavelength of $469 \mathrm{~nm}$. The cumulative amount of astaxanthin that penetrates through the membrane is calculated [15].

\section{RESULTS}

The self-nanoemulsifying preparation is an anhydrous homogenous liquid mixtures consisting of oil, surfactant, drug, and co-surfactant, which spontaneously form oil-in-water nanoemulsion upon dilution with water under gentle stirring [10]. Adding surfactant and cosurfactant into systems increases drug dissolution and formulation dispersibility during dilution with the aqueous medium of GIT. During dilution with water, active substance dissolves in the oil phase and/or surfactant, which forms a film between the oil and water phase [10]. The right type and ratio of the oil phase, surfactant and co-surfactant are critical parameters in the formation of nanoemulsion. Based on our previous study, the best ratio between sunflower oil as oil phase, Kolliphor® RH40 as surfactant, and PEG 400 as co-surfactant was $1: 8: 1$, respectively $[3,9]$. Our results showed that astaxanthin nanoemulsion had droplet size in the nanorange $(20-30 \mathrm{~nm})$ with polydispersity index was less than 0.5 , i.e. 0.2-0.3 (fig. 1) and zeta potential value was more than- $20 \mathrm{mV}$ (fig. 2).

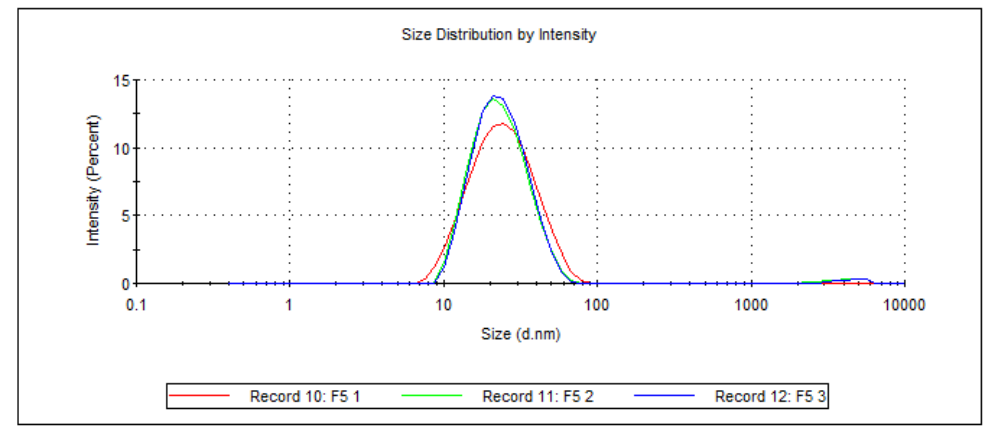

Fig. 1: Particle size analysis of nanoemulsion

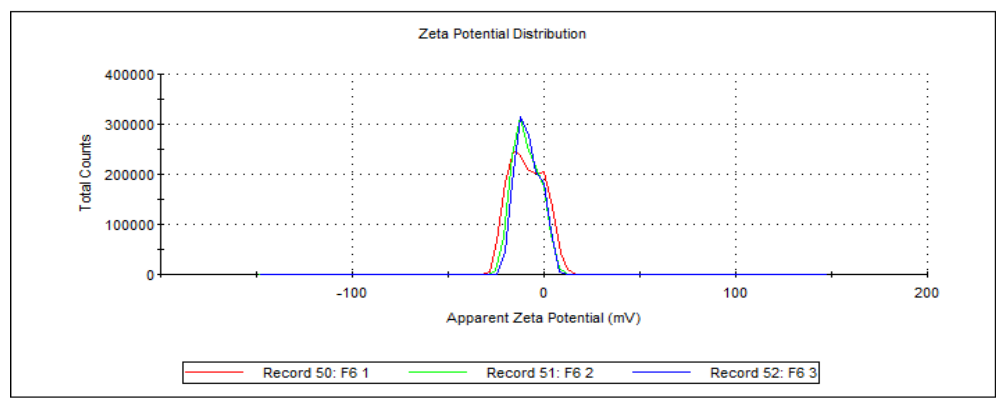

Fig. 2: Zeta potential analysis of nanoemulsion 
The Serum properties containing astaxanthin nanoemulsion prepared with carbomer as Gelling agent are presented in table 2.

The results in table 2 shows that serum nanoemulsion astaxanthin has organoleptic characteristics odorless,clear and orange and homogeneous with the $\mathrm{pH}$ value still in the $\mathrm{pH}$ range of the skin and with viscosity value showing the ease of flow properties and good spreadability on the skin.
In vitro permeation tests were conducted as simulations to see the drug's ability to penetrate biological membranes after being formulated. The biological membrane chosen in this experiment was the release of the skin of the Python reticulatus ventral part which is relatively difficult to penetrate because it has a low coefficient of permeability [16]. Diffusion test results of astaxanthin serum nanoemulsion preparations can be seen in fig. 3 .

Table 2: Physical and chemical properties of serum nanoemulsion astaxanthin

\begin{tabular}{lll}
\hline Parameters & F1 & F2 \\
\hline Visual properties serum & Odorless,clear, colorless & Odorless,clear, Orange \\
pH of serum & $4.7 \pm 0.02$ & $5.2 \pm 0.01$ \\
Viscosity value (cps) & $236 \pm 0.07$ & $1096 \pm 0.05$ \\
Homogeneity Test & Homogeneous & Homogeneous \\
Spreadability Test $(\mathrm{cm})$ & $9.9 \pm 0.20$ & $7.8 \pm 0.10$ \\
\hline
\end{tabular}

*Values are given as mean \pm standard deviation $(n=3)$.

Table 3: The results of cycling test of serum nanoemulsion astaxanthin

\begin{tabular}{|c|c|c|c|}
\hline Cycles & Parameters & F1 & F2 \\
\hline \multirow[t]{3}{*}{1} & Visual properties & Odorless,clear,colorless & Odorless,clear,orange \\
\hline & $\mathrm{pH}$ & 4.3 & 5.2 \\
\hline & Homogeneity & homogeneous & homogeneous \\
\hline \multirow[t]{3}{*}{2} & Visual properties & Odorless,clear,colorless & Odorless,clear,orange \\
\hline & $\mathrm{pH}$ & 4.2 & 5.0 \\
\hline & Homogeneity & homogeneous & Homogeneous \\
\hline \multirow[t]{3}{*}{3} & Visual properties & Odorless,clear,colorless & Odorless,clear,orange \\
\hline & $\mathrm{pH}$ & 4.2 & 4.9 \\
\hline & Homogeneity & Homogeneous & Homogeneous \\
\hline 4 & Visual properties & Odorless,clear,colorless & Odorless,clear,orange \\
\hline \multirow[t]{2}{*}{. } & $\mathrm{pH}$ & 4.1 & 4.9 \\
\hline & Homogeneity & Homogeneous & Homogeneous \\
\hline \multirow[t]{3}{*}{5} & Visual properties & Odorless,clear,colorless & Odorless,clear,orange \\
\hline & $\mathrm{pH}$ & 4.1 & 4.9 \\
\hline & homogeneity & Homogeneous & Homogeneous \\
\hline \multirow[t]{3}{*}{6} & Visual properties & Odorless,clear,colorless & Odorless,clear,orange \\
\hline & $\mathrm{pH}$ & 4.1 & 4.9 \\
\hline & homogeneity & Homogeneous & Homogeneous \\
\hline
\end{tabular}

The results in table 3 shows that the results of cycling tests showed no organoleptic changes covering color and smell but at pH values there was a decrease until the 6 th cycle when storage at $40 \pm 2{ }^{\circ} \mathrm{C} / 75 \pm 5 \% \mathrm{RH}$.

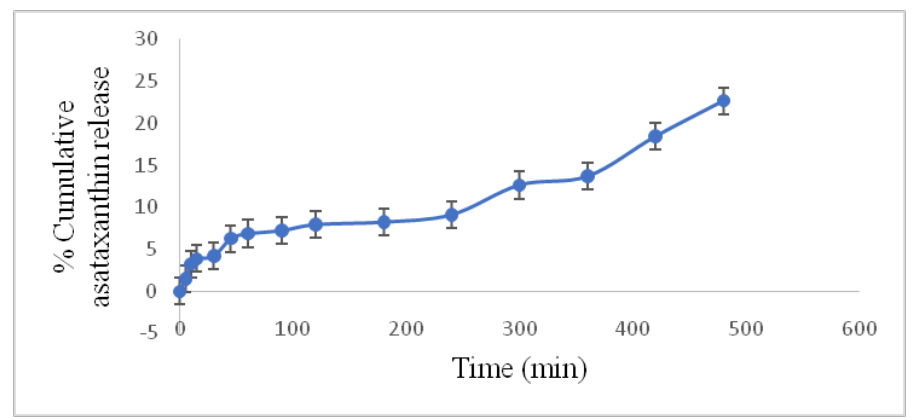

Fig. 3: In vitro permeation studies astaxanthin nanoemulsion serum

\section{DISCUSSION}

The formulation of nanoemulsions relies on an understanding of the spontaneous nano emulsification process as well as the physical and biological properties of each component used. Factors that influence the process of spontaneous nano emulsification formation are the physical properties and phase concentrations of oil, surfactant, and co-surfactants; ratio of each component, in particular the ratio of oil to surfactants; the temperature, stirring speed and $\mathrm{pH}$ of the water phase when nano emulsification is formed; physical properties of the drug, such as hydrophilicity/lipophilicity, pKa, and polarity [17].
The concentration of surfactants inside the nanoemulsion can affect the globule size of the formed nanoemulsion. The higher the concentration of surfactants used, the smaller the size of the globul formed. This is due to the decrease in the surface tension of the oil phase and the water phase, which results in the formation of the micellar. The higher the concentration of surfactants used, the more and tighter the surfactant molecules located on the surface of the misel formed [18].

The results in table 1 shows that astaxanthin nanoemulsion had droplets size in the nano-range (20-30 nm) with polydispersity 
index was less than $0.5(0.2-0.3)$ and zeta potential value was more than $(-20) \mathrm{mV}$ can be seen in table 2. Particle size test results will affect the rate of dissolution, diffusion and absorption of a drug [17]. This polydispersity index provides information on the physical stability of a dispersion system. Low polydispersity index values indicate that the dispersion system formed is more stable for the long term. Zeta's potential value can indicate the stability of a system containing dispersed globules through the presence of a repulsion force between the same charged particles when close together. The result indicates that As-SNE was stabilized sterically, because the system contains non-ionic surfactant polymer [19].

In this study, the results of the organoleptic test of serum preparations include the form of color and odor. These parameters are influenced by the active substance added to the serum base. Spreadability test was carried out to determine the ability of the preparation to spread on the skin surface. The greater the spreadability, the greater the amount of preparation that can reach the application area (stratum corneum) on the skin so that the active substance can be spread evenly. Spreadability is inversely proportional to viscosity where the lower the viscosity, the wider the spread, so that the contact between the drug and the skin is wider and the absorption of the drug into the skin will be faster [20]. As in table 2. formulas with low viscosity have a wide spreadability and instead. In addition, the dispersion can be affected by pressure, the higher the pressure, the wider the dispersion.

Viscosity measurement aims to determine the viscosity of serum preparations that will affect the spreadability when applied to the skin. In table 2 the viscosity of serum astaxanthin preparations ranges from 236-1097 cPs and good viscosity values are within the range of between $230-1150 \mathrm{cPs}$. The homogeneity test aims to see and determine the mixing of serum preparation ingredients. The results of the homogeneity test of all formulas showed a homogeneous preparation, where the preparation was marked as having no coarse grains when applied to a piece of glass. The $\mathrm{pH}$ measurement aims to determine the resulting preparation is acceptable for skin $\mathrm{pH}$ because it can cause skin irritation if it is not in accordance with the skin $\mathrm{pH}$. From the results of the $\mathrm{pH}$ test, serum preparations have a $\mathrm{pH}$ range of 4.7-5.2 where the $\mathrm{pH}$ is in the range that is allowed for the skin, namely 4.0-5.5 [21].

Based on the results of stability tests using a cycling test for 6 test cycles at room temperature storage and at $40{ }^{\circ} \mathrm{C}$, it shows that serum preparations containing astaxanthin nanoemulsion did not change from a physical point of view ranging from color, odor and clarity. From the $\mathrm{pH}$ value it shows there is a change but it is still in the skin $\mathrm{pH}$ range. The result of the stability test can be seen in table 3. The development of astaxanthin in nanoemulsions can increase stability because by making nanoemulsion, astaxanthin can be protected from exposure to external conditions because it is in a carrier system so that it can increase stability and slow down the degradation of astaxanthin during the storage process and prevent degradation. One of the advantages of nanoemulsion is the enhanced stability of the therapeutic agents [10]. When astaxanthin is incorporated into the nanoemulsion system, it will dissolve in the oil phase and enter the core of the micelles system, which is thermodynamically stable [22]. The right combination between surfactant and co-surfactant will protect the core of the micelles from the environment $[23,24]$.

At the end of the study, diffusion assays were performed to measure the cumulative percent of astaxanthin released across biological membranes. The result of the diffusion test can be seen in fig. 3 . The kinetics of drug release from the polymer matrix depends on the physicochemical properties of the materials used and the morphology of the system [25]. Variations in $\mathrm{pH}$ or temperature can cause an increase or decrease in the rate of erosion or polymer dissolution [26]. Astaxanthin cumulative release test in vitro from astaxanthin nanoemulsion serum preparation showed that Astaxanthin release continues to increase with time.

\section{CONCLUSION}

In this study, a nanoemulsion based serum formulation for topical administration was successfully developed to deliver lipophilic agents such as astaxanthin. The astaxanthin nanoemulsions had good physical characteristics, good stability and were able to increase the cumulative permeation percent of astaxanthin with increasing time.

\section{FUNDING}

Nil

\section{AUTHORS CONTRIBUTIONS}

All the authors contributed equally.

\section{CONFLICT OF INTERESTS}

\section{Declared none}

\section{REFERENCES}

1. Stambler I. Recognizing degenerative aging as a treatable medical condition: methodology and policy. Aging Dis. 2017;8(5):583-9. doi: 10.14336/AD.2017.0130, PMID 28966803.

2. Saez GT. DNA damage and repair in degenerative diseases 2016. Int J Mol Sci. 2017;18(1). doi: 10.3390/ijms18010166, PMID 28275213.

3. Nurdianti L, Rusdiana T, Sopyan I, Putriana NA, Aiman HR, Fajria TR. Characteristic comparison of an intraoral thin film containing astaxanthin nanoemulsion using sodium alginate and gelatin polymers. Turk J Pharm Sci. 2021;18(3):289-95. doi: 10.4274/tjps.galenos.2020.25483, PMID 34157818.

4. Choi HD, Kang HE, Yang SH, Lee MG, Shin WG. Pharmacokinetics and first-pass metabolism of astaxanthin in rats. Br J Nutr. 2011;105(2):220-7. doi: 10.1017/S0007114510003454, PMID 20819240.

5. Ambati RR, Phang SM, Ravi S, Aswathanarayana RG. Astaxanthin: sources, extraction, stability, biological activities and its commercial applications- a review. Mar Drugs. 2014;12(1):12852. doi: 10.3390/md12010128, PMID 24402174.

6. Affandi MMRMM, Julianto $T$, Majeed ABA. Enhanced oral bioavailability of astaxanthin with droplet size reduction. Food Sci Technol Res. 2012;18(4):549-54. doi: 10.3136/fstr.18.549.

7. Andarwulan N, Faradilla RHF. Pewarna alami untuk pangan. Bogor: Sea Fast Center; 2021.

8. Nurdianti L, Aryani R, Indra I. Formulasi dan karakterisasi SNE (Self Nanoemulsion) astaxanthin dari Haematococcus pluvialis sebagai super antioksidan alami. J Sains Farm Klin. 2017;4(1):36-42.

9. Krstic M, Medarevic D, Duris J, Ibric S. Self-nanoemulsifying drug delivery systems (SNEDDS) and self-microemulsifying drug delivery systems (SMEDDS) as lipid nanocarriers for improving dissolution rate and bioavailability of poorly soluble drugs. Lipid nanocarriers for drug targeting. William Andrew Publishing; 2018. p. 473-508.

10. Date AA, Desai N, Dixit R, Nagarsenker M. Self-nanoemulsifying drug delivery systems: formulation insights, applications and advances. Nanomedicine (Lond). 2010;5(10):1595-616. doi: 10.2217/nnm.10.126, PMID 21143036.

11. Nurdianti L, Nurdin A, Pratita ATK, Wulandari WT. Comparison of ethanol emulgel extract activity of Duku fruit peels (Lansium domesticum Corr) with tranexamic acid as a skin lightener. J Glob Pharm Technol. 2020;12(01):244-52.

12. Indriaty S, Rizikiyan Y, Firmansyah D. Formulasi dan uji stabilitas gel antiaging dari kombinasi ekstrak etanol kulit buah naga merah (Achatina fulica) dengan variasi gelling agent carbomer 940. J Pharmacopolium. 2019;2(2):104-11.

13. Zulkarnain K, Lotion SFS. O/W Dan W/O ekstrak buah mahkota dewa sebagai tabir surya dan Uji Iritasi Primer pada kelinci. Yogyakarta: Gadjah Mada university Press Yogyakarta; 2013.

14. Septiani S, Nasrul W, Soraya R. Formulasi sediaan masker gel antioksidan dari ekstrak etanol biji melinjo (gnetum gnemon Linn.). J UNPAD. 2011;1(1):4-24.

15. Nurdianti L, Setiawan F, Indra AR, Mudhakir D, Anggadiredja K. Nanoemulsion based Gel formulation of astaxanthin for enhanced permeability: potential as a transdermal drug delivery system. Int J Pharm Sci Rev Res. 2018;52(2):55-9.

16. Tay SLM, Heng PWS, Chan LW. An investigation of the chick chorioallantoic membrane as an alternative model to various biological tissues for permeation studies. J Pharm Pharmacol. 
2011;63(10):1283-9. doi: 10.1111/j.2042-7158.2011.01338x, PMID 21899543.

17. Baloch J, Sohail MF, Sarwar HS, Kiani MH, Khan GM, Jahan S, Rafay M, Chaudhry MT, Yasinzai M, Shahnaz G. Selfnanoemulsifying drug delivery system (SNEDDS) for improved oral bioavailability of chlorpromazine: in vitro and in vivo evaluation. Medicina (Kaunas). 2019;55(5):210. doi: 10.3390/medicina55050210, PMID 31137751.

18. Burlatsky SF, Atrazhev VV, Dmitriev DV, Sultanov VI, Timokhina EN, Ugolkova EA, Tulyani S, Vincitore A, et al. Surface tension model for surfactant solutions at the critical micelle concentration. J Colloid Interface Sci. 2013;393:151-60. doi: 10.1016/j.jcis.2012.10.020, PMID 23153677.

19. Nurdianti L, Rusdiana T, Sopyan I. Antidiabetic activity of thin film containing astaxanthin-loaded nanoemulsion using carboxymethylcellulose sodium polymer on alloxan-induced diabetic rabbit. J Adv Pharm Technol Res. 2020;11(4):189-93. doi: 10.4103/japtr.JAPTR_55_20, PMID 33425703.

20. Maulidaniar R, Rahima SR, Rita M, Hamidah N, Yuda AW. Gel Asam Salisilat. Universitas lambung Mangkurat Banjar; 2011.

21. Priani SE, Darusman F, Humanisya H. Formulasi sediaan emulgel antioksidan mengandung ekstrak etanol kulit batang kayu manis (Cinnamomum Burmani Nees Ex. Bl). Prosiding SnaPP2014 Sains, Teknologi dan Kesehatan. 2014;4(1).

22. Higuera Ciapara I, Felix Valenzuela L, Goycoolea FM, Arguelles Monal W. Microencapsulation of astaxanthin in a chitosan matrix. Carbohydr Polym. 2004;56(1):41-5. doi: 10.1016/ j.carbpol.2003.11.012.

23. Guideline, IHT. Stability testing of new drug substances and products. Current Step. 2003;4:1-24.

24. Nurdianti L, Sopyan I, Rusdiana T. Formulation, characterization, and stability study of fast dissolving thin film containing astaxanthin nanoemulsion using hydroxylpropropylmethyl cellulose polymers. Int J Appl Pharm. 2021;13(3):17-22.

25. Sudhakar Y, Kuotsu K, Bandyopadhyay AK. Buccal bioadhesive drug delivery--a promising option for orally less efficient drugs. J Control Release. 2006;114(1):15-40. doi: 10.1016/ j.jconrel.2006.04.012, PMID 16828915.

26. Taylor MJ, Tanna S, Sahota T. In vivo study of a polymeric glucose-sensitive insulin delivery system using a rat model. J Pharm Sci. 2010;99(10):4215-27. doi: 10.1002/jps.22138, PMID 20737629. 